\title{
O CADERNO DE UMA PROFESSORA-ALUNA E AS PROPOSTAS PARA O ENSINO DA ARITMÉTICA NA ESCOLA ATIVA (MINAS GERAIS, DÉCADA DE 1930)
}

\author{
Nelma Marçal Lacerda Fonseca \\ Universidade Federal de Minas Gerais, Brasil. \\ Diogo Alves de Faria Reis \\ Universidade Federal de Minas Gerais, Brasil. \\ Maria Laura Magalhães Gomes \\ Universidade Federal de Minas Gerais, Brasil. \\ Luciano Mendes de Faria Filho \\ Universidade Federal de Minas Gerais, Brasil.
}

\section{$\cos 80$}

\begin{abstract}
Resumo
O artigo versa sobre o caderno de Metodologia da Aritmética de Imene Guimarães, aluna da professora Alda Lodi (1898-2002) na segunda turma da Escola de Aperfeiçoamento de Minas Gerais. Alda Lodi participou do grupo de docentes enviadas pelo governo mineiro ao Teacher's College, nos Estados Unidos, para se prepararem para atuar na formação de professoras primárias em exercício no contexto das reformas educacionais de 1927-1928. Considerando a relevância, as potencialidades e os limites dos cadernos escolares como fonte, os registros desse caderno de 1932 são estudados e cotejados com outros materiais, em busca de uma compreensão inicial dos modos de apropriação das propostas para o ensino da Aritmética no momento da adesão ao ideário da escola ativa em Minas Gerais.

Palavras-chave: cadernos escolares, metodologia da Aritmética, Escola de Aperfeiçoamento de Minas Gerais, Alda Lodi, história da educação matemática brasileira.
\end{abstract}




\title{
A TEACHER'S NOTEBOOK AND THE PROPOSALS FOR TEACHING ARITHMETIC IN ACTIVE SCHOOL (MINAS GERAIS, 1930)
}

\begin{abstract}
The article focuses on a notebook which belonged to Imene Guimarães, a student of professor Alda Lodi (1898-2002) in Escola de Aperfeiçoamento, an institution of continuing education for teachers created by educational reforms promoted by the government of the state of Minas Gerais in 1927-1928. Alda Lodi taught Methodology of Arithmetic in this institution. Considering the relevance, potentialities and limitations of school notebooks as a source for the history of education, the records of this notebook of 1932 are studied and compared with other materials for the purpose of an initial understanding of the modes of appropriation of proposals for renovating the teaching of Arithmetic according to the ideas associated to active school in Minas Gerais.

Keywords: school notebooks, methodology of Arithmetic, Escola de Aperfeiçoamento de Minas Gerais, Alda Lodi, history of mathematics education in Brazil.

\section{EL CUADERNO DE UNA DOCENTE-ALUMNA Y LAS PROPUESTAS PARA LA ENSEÑANZA DE LA ARITMÉTICA EN LA ESCUELA ACTIVA (MINAS GERAIS, DÉCADA DE 1930)}

\section{Resúmen}

El artículo tiene como tema el cuaderno de Metodología de la Aritmética de Imene Guimarães, alumna de la docente Alda Lodi (1898-2002) en la segunda turma de la Escola de Aperfeiçoamento de Minas Gerais. Alda Lodi participó del grupo de docentes enviadas por el gobierno minero al Teacher's College, en Estados Unidos, para que se prepararan para actuar en la formación de maestras en ejercicio en el contexto de las reformas educativas de 1927-1928. Considerando la relevancia, las potencialidades y los límites de los cuadernos escolares como fuente, los registros que contiene ese cuaderno de 1932 son estudiados y comparados con otros materiales, en la búsqueda de una comprensión inicial de los modos de apropiación de las propuestas para la enseñanza de la Aritmética cuando de la adhesión al ideario de la escuela activa en Minas.

Palabras-clave: cuadernos, metodología de la Aritmética, Escola de Aperfeiçoamento de Minas Gerais, Alda Lodi, historia de la educación matemática en Brasil.

\section{LE CAHIER D'UNE ÉLÈVE-ENSEIGNANT ET LES PROPOSITIONS POUR L'ENSEIGNEMENT DE L'ARITHMÉTIQUE À L'ÉCOLE ACTIVE (MINAS GERAIS,1930)}

\section{Résumé}

L'article se concentre sur un ordinateur portable qui appartenait à Imene Guimarães, une élève du professeur Alda Lodi (1898-2002) dans Escola de Aperfeiçoamento, une institution de formation continue pour les enseignants créée par les réformes éducatives promues par le gouvernement de l'état de Minas Gerais au 1927-1928. Alda Lodi a enseigné la méthodologie de l'Arithmétique dans cette institution. Compte tenu de la pertinence, les potentialités et les limites des cahiers d'école en tant que source pour l'histoire de l'éducation, les dossiers de ce portable de 1932 sont étudiées et comparées avec d'autres matériaux dans le but d'une compréhension initiale des modes d'appropriation des propositions pour la rénovation du l'enseignement de l'Arithmétique selon les idées associées à l'école active dans Minas Gerais.

Mots-clé: cahiers d'écolier, méthodologie de l'Arithmétique, Escola de Aperfeiçoamento de Minas Gerais, Alda Lodi, l'histoire de l'enseignement des mathématiques au Brésil. 


\section{Introdução: um caderno}

7 emos conosco um caderno. É do tipo brochura e mede $6,5 \mathrm{~cm}$ por $8,5 \mathrm{~cm}$. O caderno está bem conservado: a capa e as 28 folhas não estão amassadas ou rasgadas. A primeira dessas folhas está em branco, mas todas as demais páginas estão escritas a lápis, com registros bem legíveis. A capa tem estampa geométrica em duas cores, preto e bege, em papel de gramatura mais espessa do que a do papel das páginas. Em caligrafia cursiva, essa capa traz dois nomes e uma data, assim grafados: D. Alda - Imene Guimarães - 14-8-932.

Figura 1

Capa do caderno de Imene Guimarães - 1932.

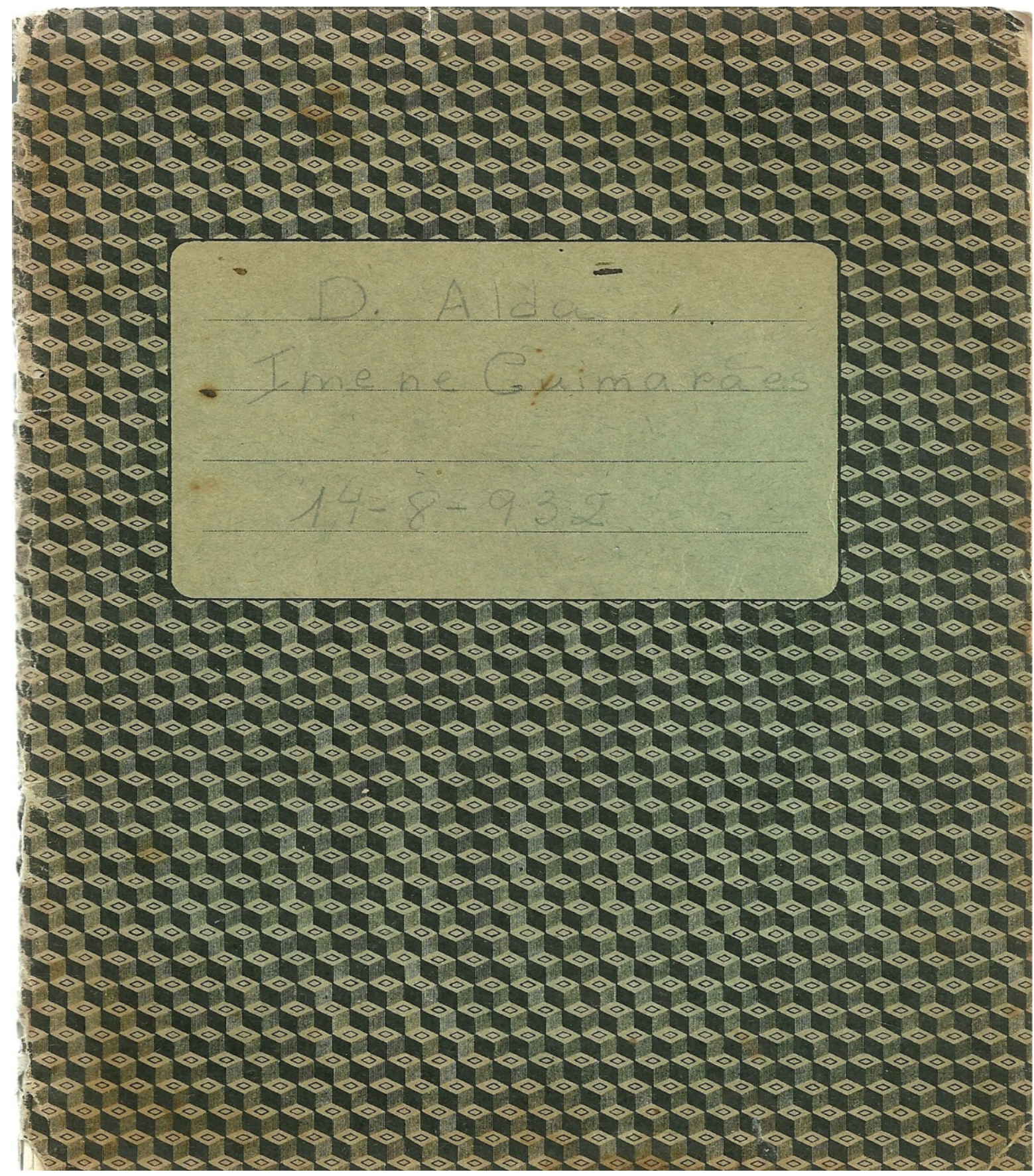


Ao folhear o caderno, encontramos sete datas, escritas da mesma forma que a data da capa ao longo de suas páginas: 13-8-932, 19-8-932, 20-8-932, 26-8-932, 27-8-932, 318-932 e 2-9-932. Uma rápida olhada nos mostra imediatamente que o caderno contém anotações de aulas que abordam a Aritmética, pois suas primeiras linhas ${ }^{1}$, logo após a data, dizem:

Já vimos então 3 grupos de factos na multiplicação:

$\left.1^{\circ}\right)$ multiplicações sem reserva

$2^{\circ}$ ) multiplicações com reserva

$3^{\circ}$ ) multiplicações em que entram zeros, com um só algarismo no multiplicador.

Figura 2

Primeira página do caderno de Imene Guimarães - 1932

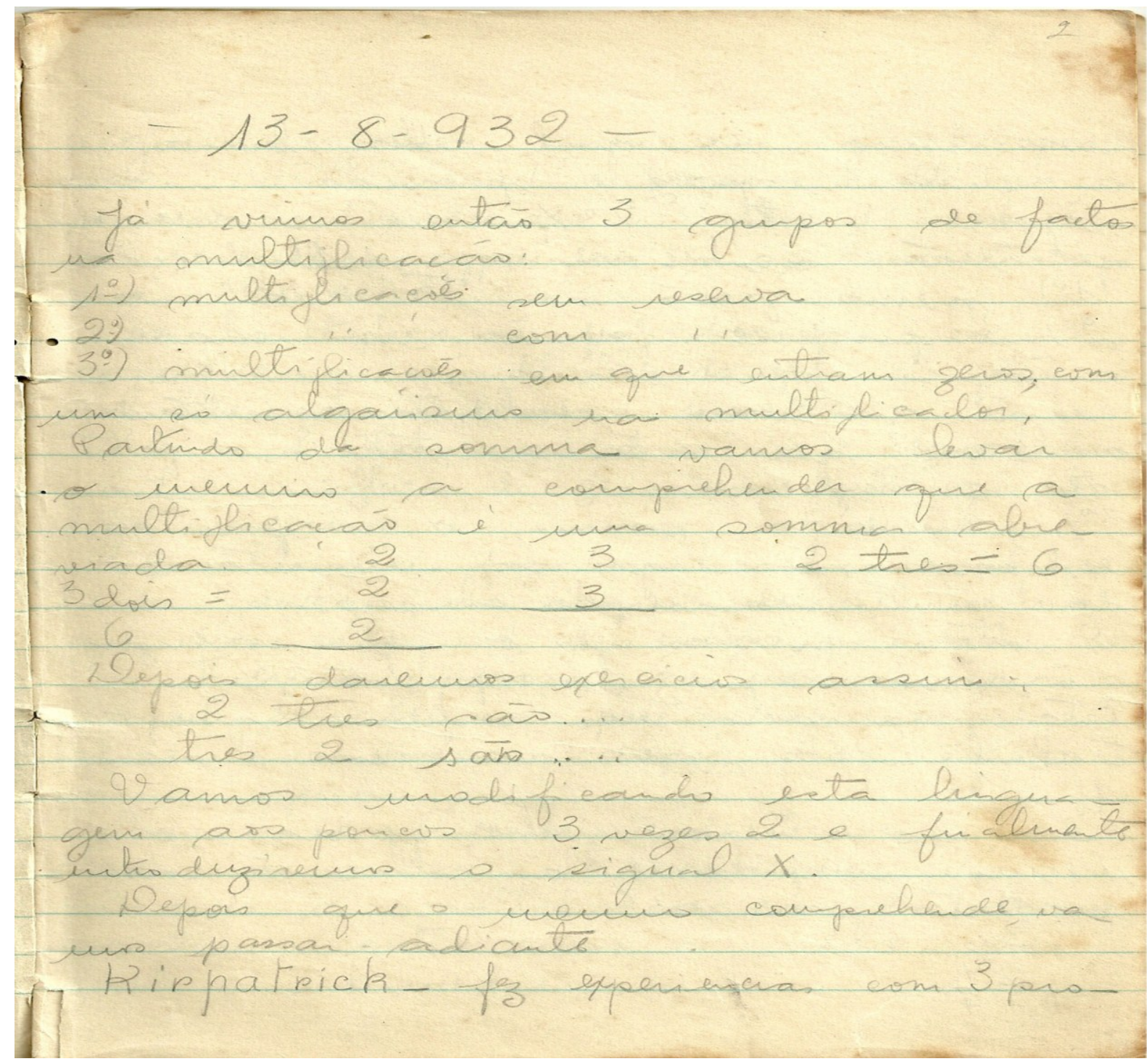

${ }^{1}$ Em todo este texto transcrevemos o que está no caderno com a grafia e a pontuação originais. Optamos, ainda, por numerar as páginas anotadas do caderno do número 1 ao número 54 , para referência às passagens aqui citadas. 
Alguns subtítulos se destacam por estarem sublinhados ou colocados em posição central na linha em que se inscrevem, em meio às anotações ao longo das 54 páginas escritas: Divisão, Factos fundamentaes, Divisão do trabalho, Diagnóstico de erros, Penetração das cousas sociaes, Problemas reaes. Encontramos uma grande quantidade de operações aritméticas armadas, sobretudo divisões, além de alguns problemas de Aritmética acompanhados da operação que leva à sua solução. Há, também, textos de tamanhos variados, nos quais são apresentados aspectos a serem levados em conta no ensino dos conteúdos aritméticos abordados no caderno às crianças. O caderno trata, portanto, de alguns conhecimentos da Aritmética e dos modos de ensiná-los a crianças.

O caderno em nossas mãos que, no momento em que escrevemos, tem mais de 80 anos, escapou do descarte, e, embora um pouco desbotado pelo tempo, foi preservado em meio aos mais de três mil documentos do arquivo ${ }^{2}$ da professora mineira Alda Lodi (1898-2002). O caderno pertenceu a sua aluna Imene Guimarães, que registrou nele aulas ministradas pela docente nos meses de agosto e setembro de 1932.

\section{Cadernos escolares como fonte e objeto de pesquisa em História da Educação}

Os arquivos de pessoas ligadas à educação, para alguns pesquisadores (Mignot, 2008, Viñao, 1998, 2002, 2008; Gvirtz, 1997, 1999; Gvirtz e Larrondo, 2008; Chartier, 2002, 2007, 2007a; Vidal, 2005), têm emergido como uma recorrente temática para a realização de pesquisas na área da história da educação. Nesses arquivos, além de documentos pessoais, podem ser encontrados documentos de caráter pedagógico e institucional de fundamental importância para a historiografia desses espaços. Tais documentos, como atas de exames, boletins de frequência e de avaliações, diários de classe, livro de assinaturas de ponto, currículos, atos disciplinares, mapas estatísticos, planos de aulas, apostilas, livros, atas de reuniões, fotos, cadernos de classe de exalunos, dentre outros, podem revelar uma realidade até então desprezada ou não apreendida nos documentos oficiais.

De acordo com Diana Vidal (2005), é preciso reconhecer que não há prática escolar desligada das condições materiais de sua efetivação. Assim, os objetos preservados portam pistas das múltiplas maneiras como professores e alunos constituíram inteligibilidades e suscitam a investigação sobre as diferentes formas de apropriação desses conhecimentos, "oferecendo ao pesquisador índices sobre as relações pretéritas dos sujeitos com a materialidade escolar ou sobre a formalidade das práticas escolares, e fazendo-o recordar que as situações pedagógicas se constroem muito frequentemente por formas orais de socialização." (2005, p. 24).

Os cadernos escolares têm se tornado, há algum tempo, objeto de interesse da pesquisa em história da educação. Entre outros pesquisadores, Mignot (2008a), no artigo introdutório do livro (Mignot, 2008) que organizou sobre o tema, chamou a atenção para a invisibilidade anterior desse tipo de material, valorizado atualmente, no seio da ampliação contemporânea da noção de documento, como fonte ou objeto de investigação. A autora também salienta o fato de que cadernos costumam escapar da guarda e preservação nos

\footnotetext{
${ }^{2}$ Esse acervo foi doado, em 2005, pela família de sua dona, ao Museu da Escola de Minas Gerais, ligado à Secretaria de Estado da Educação de Minas Gerais. Sob a liderança de Nelma Marçal Lacerda Fonseca, o acervo, higienizado e organizado, passou a constituir o Arquivo Alda Lodi que, atualmente, está abrigado no bairro Gameleira, na região oeste de Belo Horizonte, em dependências da secretaria estadual mencionada. 
museus ou arquivos escolares, ficando abandonados em gavetas, caixas e armários, quando não são jogados fora ou destruídos por seus próprios donos ou outros, nas mudanças e inevitáveis descartes de papéis durante a vida.

Mignot (2008a) aponta algumas razões para explicar a existência rarefeita desse material em arquivos, tais como "a legislação brasileira sobre arquivos escolares; a valorização de documentos tidos como oficiais em detrimento daqueles que tratam da cotidianidade da instituição; a ênfase das pesquisas sobre a legislação e os legisladores" (p. 7). No entanto, devemos considerar, também, a própria economia da conservação, que leva pessoas e instituições a guardarem aquilo que consideram mais relevante para suas políticas de memória individuais ou coletivas. Mais recentemente os cadernos têm recebido destaque nas pesquisas históricas sobre a educação e temos presenciado o aparecimento de diversos estudos que os envolvem como fonte ou objeto ${ }^{3}$.

Os estudos de Hébrard (1995) e de Silvina Gvirtz (1999) evidenciaram os cadernos escolares como um relevante objeto para a historiografia da educação, que oferecem pistas importantes sobre o cotidiano escolar. Anne-Marie Chartier destaca que, devido à sua fragilidade, os cadernos escolares acabam sendo um material pouco utilizado nas pesquisas históricas, mas enfatiza que eles são capazes de fornecer "testemunhos insubstituíveis a respeito dos exercícios escolares, das práticas pedagógicas e do desempenho dos alunos no contexto da sala de aula" (2007, p. 13). Nesse sentido, é possível descortinar o ensino desejado com o aprendizado praticado, passando da teoria à prática. A autora ainda esclarece que esses documentos "constituem uma fonte descontínua, elíptica, que se torna ainda mais rara quanto mais se afasta no tempo. Essa fonte é, ao mesmo tempo, fascinante e enigmática, difícil de tratar e de interpretar, justamente por sua aparente banalidade" (Chartier, 2007a, p. 23).

Nessa direção, Antonio Viñao ressalta que os cadernos escolares são considerados como "uma fonte, não menos complexa que outras, que durante as duas últimas décadas vem figurando no cruzamento de três campos historiográficos relacionados, inclusive complementares, mas com diferentes enfoques e interesses: a história da infância, a da cultura escrita e a da educação" (2008, p. 15). O autor afirma, ainda, que os cadernos escolares são, ao mesmo tempo, uma produção infantil, um espaço gráfico e um produto da cultura escolar. Desse modo, os cadernos escolares podem ser considerados como um produto da cultura escolar e não apenas como um produto da atividade diária da sala de aula, tornando-se uma fonte-objeto de potencial estudo que pode fornecer indícios "da realidade material da escola e do que nela se faz" (Vinão, 2008, p. 16).

No mesmo sentido, Gvirtz e Larrondo (2008) consideram que os cadernos escolares são fontes privilegiadas de pesquisa, primeiramente, por serem usados diariamente pelos alunos, servindo tanto para registrar mensagens e desenvolver atividades quanto para conservá-los; em segundo lugar, por ser um espaço de interação entre professores e alunos, possibilitando que sejam verificados os efeitos dessa interação.

A definição de cadernos escolares, de acordo com Viñao (2008), é simples. Para ele trata-se de um conjunto de folhas costuradas de antemão em forma de livro que formam uma unidade ou volume, que são utilizados com fins escolares e que podem ou não ter a

\footnotetext{
${ }^{3}$ Devemos mencionar, a este respeito, o trabalho pioneiro de Silvina Gvirtz (1997). Outros exemplos são Mignot (2008), Leme da Silva e Valente (2008) e Peres (2012). 
capa personalizada ou padronizada, grandes ou pequenos, com linhas ou não com margens, espessuras e folhas diferentes.

Em relação aos tipos de estudo ou pesquisas cujo enfoque são os cadernos escolares, Viñao ressalta que eles são utilizados como

fonte para o conhecimento das imagens e representações sociais sobre a infância, a escola, a família e outros temas similares; como instrumentos de aculturação escrita; como veículos transmissores de valores e atitudes ou um modo de doutrinação ideológica e política; como uma forma a mais de trabalho dos alunos junto aos exercícios e folhas soltas. [...] como meio para o estudo do currículo e das diferentes disciplinas e atividades escolares; [...] como uma inovação educativa dentro do movimento internacional da Escola Nova e como um instrumento de expressão pessoal e subjetiva do aluno. (2008, p.18)

Esse autor salienta, ainda, que existem alguns estudos que visam a elaborar uma tipologia para ordenar e classificar os vários tipos de cadernos e outros com interesse em suas características como objeto de pesquisa em relação às possibilidades e limites como fonte histórica.

Ao fazer uma análise dos estudos sobre cadernos escolares existentes dentro do campo da historiografia educativa, Viñao (2008) destaca três perspectivas: a primeira foca a história do currículo e das culturas escolares com o objetivo de estudar o estreitamento entre a vida cotidiana das instituições educativas e suas respectivas salas de aula. A segunda centra-se na transmissão de ideologias e valores no meio escolar com o objetivo de aproximação da realidade e das práticas escolares; por fim, tem-se a perspectiva da história das reformas e inovações educativas.

\section{Os cadernos escolares como produto da cultura escolar}

Os cadernos escolares são considerados como um produto da cultura escolar por serem vistos como um instrumento fundamental que contribui para organizar o trabalho realizado em sala de aula e por possibilitarem uma aproximação dos tempos - ritmos, sequências, momentos - reais da atividade escolar. Como produto da cultura escolar, Viñao (2008) indica que os cadernos escolares refletem a cultura própria do nível, etapa ou ciclo de ensino em que são utilizados.

Por outro lado, Viñao (2008) e Anne-Marie Chartier (2002) indicam que os cadernos escolares constituem um objeto que, junto com o livro texto e o quadro de horário, falam sobre o processo de apropriação e interiorização dos saberes, tarefas e disciplinas escolares, pelos alunos.

A possibilidade de reconstrução do currículo real, por meio apenas dos cadernos escolares, deve ser descartada. Vinão enfatiza que "o máximo que podemos fazer é nos aproximarmos do passado e reconstruí-lo de modo parcial e com um enfoque determinado" (2008, p. 25).

No mesmo sentido, Gvirtz e Larrondo (2008) esclarecem que é possível compreender o caderno como produto da cultura escolar, por este pertencer a uma instituição específica, na qual atua como dispositivo, transformando os saberes, valores ou ideologias em "outra coisa" (p. 39). 
Nos últimos anos surgiram várias investigações que utilizam os cadernos escolares como fonte primária de pesquisa. Esses estudos se valem do caderno escolar em áreas tais como: currículo, transmissão de ideologias e valores, estudos comparativos, desde a perspectiva história e presente.

A utilização dos cadernos escolares como fonte-objeto de pesquisa se dá na medida em que esses documentos refletem o dia a dia escolar, possibilitando analisar o que realmente acontece no âmbito microescolar como um nível chave para analisar o ato educativo e para encurtar distâncias entre o que se diz e o que se faz, uma vez que os cadernos permitem uma aproximação efetivamente do que se ensina na sala de aula. (Gvirtz, 1997).

Os cadernos escolares que os alunos usam diariamente reúnem, de acordo com Gvirtz (1999), duas condições interessantes: a primeira, sua capacidade de conservar o que foi registrado, distinguindo-os, assim, de outros espaços de escrita. A segunda condição se refere ao fato de os cadernos escolares representarem um espaço de interação entre professores e alunos. Nesse sentido, os cadernos escolares constituem um campo significativo para observar os processos históricos, culturais e pedagógicos, podendo representar as relações de poder, relações interpessoais e, sobretudo, a produção de saberes vivenciados no cotidiano da escola.

Como mostram Gvirtz e Larrondo (2008), tem havido diversas pesquisas sobre cadernos escolares em vários países, inclusive no Brasil. No arquivo pessoal de Alda Lodi, os cadernos encontrados, entre eles o de Imene Guimarães, aqui focalizado, são diferentes do que é usualmente chamado de caderno escolar. Os cadernos desse arquivo pertenceram a professoras em formação continuada na Escola de Aperfeiçoamento ou no curso de Administração Escolar, que era um curso superior para formar professoras. Alguns desses objetos exibem apenas registros de caráter teórico-metodológico sobre as disciplinas estudadas e, muitas vezes, não apresentam atividades e nem correções. Trata-se, portanto, de cadernos escolares num sentido especial: são cadernos que pertenceram a professoras, mas que deles fizeram uso na condição de alunas da professora Alda Lodi.

\section{O caderno de Imene Guimarães, aluna da professora Alda Lodi}

Fonseca (2010) realizou um estudo sobre a formação e a atuação docentes da professora Alda Lodi, nascida em 1898 e falecida em 2002, em Belo Horizonte, no período 1912-1932. Essa docente, em sua longa vida profissional, atuou em diversos níveis de ensino e em várias instituições, desempenhou múltiplos papéis no campo do ensino e da administração da educação mineira. Alda Lodi foi uma das cinco professoras ${ }^{4}$ selecionadas pelo governo do estado de Minas Gerais para formar uma comissão enviada ao Teacher's College, na Universidade de Colúmbia, em Nova York, nos Estados Unidos, no final da década de 1920, "para aprender novos métodos e práticas educacionais para serem aplicadas nas escolas mineiras, na implantação de sua reforma de ensino" (Fonseca, 2010, p. 76). A essa professora, integrante do grupo que constituiria "o núcleo gerador do processo de renovação que se esperava nas escolas mineiras” (Peixoto, 2003,

\footnotetext{
${ }^{4}$ As outras professoras eram: Inácia Guimarães, Amélia de Castro Monteiro, Benedita Valadares e Lúcia Schmidt Monteiro de Castro (Fonseca, 2010; Peixoto, 2003; Prates, 1989). 
p. 95), coube uma missão específica: especializar-se, no curso do Teacher's College, em Metodologia da Aritmética.

Está-se falando, aqui, da reforma do ensino do Estado de Minas Gerais, realizada em 1927, comandada pelo secretário dos Negócios do Interior, Francisco Campos, e pelo diretor da Instrução Pública, Mário Casasanta, durante o governo do presidente Antônio Carlos Ribeiro de Andrada. A reforma ficou estabelecida oficialmente pela publicação dos decretos de regulamentação da educação mineira de 1927-1928, conhecidos como Reforma Educacional Francisco Campos e Mário Casasanta (Peixoto, 2003).

Como é bastante divulgado, essa reforma declarou publicamente sua concepção e princípios baseados nos ideais da escola ativa ${ }^{5}$ e incidiu profundamente nos ensinos primário e normal mineiros, com especial atenção à questão da preparação dos professores para colocar em ação suas propostas. Prates (1989, p. 90) acentua o pensamento norteador da reforma: o de que a adoção de uma base científica "permitiria ao novo professor formar e moldar (não pelos dons inatos que pudesse ter, mas pela competência científica e profissional adquirida), em cada um dos seus alunos, um cidadão inteligente, trabalhador, ajustado e cooperativo", com o qual seria possível desenvolver democraticamente o Estado e a Nação.

De acordo com Fonseca (2010), o arquivo doado pela família da professora Alda Lodi ao Museu da Escola de Minas Gerais em 2002

é composto por um conjunto diversificado de documentos: uma biblioteca em torno de 2000 livros, muitos em inglês adquiridos pela professora Alda no período de estudos em Nova York, entre 1927/1929; o diário de anotações das aulas no Teacher's College; documentos institucionais relativos à sua carreira docente e administrativa; correspondência privada e profissional; cadernetas de anotações de gastos pessoais e das instituições onde trabalhou; boletos bancários e contracheques; planos de aulas, cadernos, exercícios e provas de alunas; manuscritos; recortes e exemplares de jornais e revistas nacionais e estrangeiras; fotografias avulsas e álbuns fotográficos; trabalhos escolares e desenhos de crianças da família; diplomas; itens ligados à sua fé católica; pequenos objetos e uma grande coleção de receitas culinárias. (Fonseca, 2010, p. 25)

Integrando esse acervo tão vasto e plural, está o caderno de Imene Guimarães, exaluna da professora Alda Lodi, responsável pela disciplina de Metodologia da Aritmética na Escola de Aperfeiçoamento (Fonseca, 2010). Essa instituição foi estabelecida em 1929, como parte das reformas fixadas pela legislação educacional mineira comandadas por Francisco Campos, com o propósito específico de formar uma elite pedagógica e cientificamente preparada nos moldes do conhecimento educacional então disponível para ocupar os postos principais do ensino primário mineiro. Os professores formados no curso pós-normal de dois anos oferecido pela Escola de Aperfeiçoamento deveriam exercer as funções de docentes de escolas normais, diretores dos grupos escolares, assistentes e orientadores técnicos que difundiriam as novas ideias e técnicas de ensino aprendidas por todo o estado de Minas Gerais ${ }^{6}$ (Prates, 2000).

\footnotetext{
${ }^{5}$ Em Minas Gerais, naquele momento, como argumentam Vidal e Faria Filho (2005), devido à forte presença católica nos processos de reforma, fazia diferença falar em escola ativa ou em escola nova.

${ }^{6}$ A Escola de Aperfeiçoamento durou até 1946, ano em que foi incorporada ao Instituto de Educação de Minas Gerais, tornando-se, então, o Curso de Administração Escolar (Prates, 1989). 
Conforme a investigação de Fonseca (2010), Alda Lodi regressou dos Estados Unidos em agosto de 1929 e, logo em seguida, assumiu a responsabilidade pela disciplina Metodologia da Aritmética na Escola de Aperfeiçoamento. Segundo Prates (1989), juntamente com as professoras Lúcia Schmidt Monteiro de Castro, posteriormente a seu casamento chamada Lúcia Casasanta, e Amélia de Castro Monteiro, Alda Lodi esteve sempre na Escola. De acordo com a mesma autora (Prates, 2000), as disciplinas de metodologias específicas oferecidas às professoras - Língua Pátria, Aritmética, Ciências Naturais e Sociais - se destinavam tanto a "ensinar os conceitos científicos que embasavam cada uma dessas áreas" quanto a "preparar e tornar as alunas competentes na aplicação dos métodos mais pertinentes ao ensino de cada um desses campos do conhecimento." A pesquisadora destaca que o conteúdo das várias matérias que compunham o currículo da Escola de Aperfeiçoamento não fazia parte da legislação relativa à instituição ${ }^{7}$ e afirma que o corpo docente foi responsável por,

a partir da própria prática na Escola, dos ensaios e erros dos primeiros tempos, mas sempre inspirados nos conhecimentos adquiridos e nas experiências vivenciadas no exterior, elaborar, aos poucos, o programa que só foi redigido efetivamente em 1937, a pedido de Cristiano Machado, então Secretário da Educação do governo de Benedito Valadares (Prates, 2000, p. 75).

Imene Guimarães ${ }^{8}$ foi aluna da segunda turma de professoras a realizar o curso da Escola de Aperfeiçoamento (Fonseca, 2010) e seu caderno tem datas de agostosetembro de 1932, três anos após o regresso de Alda Lodi dos Estados Unidos e cinco anos antes da redação do programa aludido por Maria Helena Prates. Seu caderno constitui, então, um documento importante para "conhecermos e nos aproximarmos do currículo real" (Viñao, 2008, p. 25) da disciplina Metodologia da Aritmética ministrada pela professora Alda Lodi na Escola de Aperfeiçoamento, mesmo que acreditemos, como Antonio Viñao, que não seja possível a reconstrução do currículo real, desaparecido com o decorrer do tempo. Nem tudo está nos cadernos, que silenciam sobre as intervenções orais ou gestuais de professores e alunos, sobre como elas ocorrem ou sobre o ambiente da sala de aula. Contudo, o caderno de Imene Guimarães, ainda que não possa dizer tudo, nos apresenta pistas sobre a Metodologia da Aritmética lecionada por Alda Lodi para formar as professoras mineiras de acordo com os princípios da escola ativa defendidos nas mudanças da educação efetivadas pela legislação estadual mineira do final dos anos 1920.

\footnotetext{
${ }^{7}$ As disciplinas do curso a ser dado na Escola, mas não seus programas, eram listadas no art. $2^{\circ}$ do decreto -lei n. 8.987/1928 (Prates, 2000).

${ }^{8}$ Nascida em 8 de janeiro de 1911, Imene fez o curso primário no primeiro Grupo Escolar de Belo Horizonte, o Barão do Rio Branco. Depois de concluir o curso normal, também em Belo Horizonte, foi estagiária nesse Grupo Escolar. No governo de Antônio Carlos de Andrada, Imene foi convocada por Mário Casasanta para assumir uma turma nas Classes Anexas à Escola de Aperfeiçoamento e tornou-se professora-aluna da segunda turma da Escola (1932-1934). A professora exerceu diversas funções em sua carreira profissional, entre as quais se destacam as de orientadora técnica e diretora do Grupo Escolar Barão do Rio Branco, orientadora técnica do Instituto Pestalozzi, sob a direção de Helena Antipoff, inspetora seccional do ensino secundário e delegada do Ministério da Educação em Minas Gerais.
} 


\section{De quê e como fala o caderno}

Nosso caderno é pequeno, como já foi dito. Ele traz anotações referentes ao trabalho da disciplina Metodologia da Aritmética na Escola de Aperfeiçoamento em sete datas apenas. Esse caderno de Metodologia da Aritmética foi, provavelmente, precedido por outros referentes ao primeiro semestre de 1932, do mesmo modo como outros cadernos para a mesma disciplina devem tê-lo sucedido ${ }^{9}$. Os conteúdos tratados são, inicialmente, as operações de multiplicação e divisão de números inteiros positivos. Depreendemos que, durante o primeiro semestre, as aulas de Metodologia da Aritmética tiveram como foco a adição, a subtração e conhecimentos iniciais sobre a multiplicação, uma vez que, nesse caderno, a primeira aula anotada traz os apontamentos transcritos no início deste artigo.

Os primeiros registros do caderno tratam das dificuldades da multiplicação, apresentando-as detalhadamente, com explicações que vão se aprofundando, afirmando que o ensino da Aritmética é processual, que as etapas precisam ser respeitadas, enfatizando que a compreensão é a condição fundamental para a aprendizagem: "vamos fazer a creança comprehender devagarinho [...] se tivermos pressa, o menino não comprehende" (Lodi, 1929, p. 3).

Antes de se iniciarem os registros sobre a divisão, Imene anota uma recomendação: a de que, na organização dos exercícios, é preciso ter em vista que os 81 fatos da multiplicação precisam ser repetidos e que os mais difíceis devem ser mais repetidos do que os mais fáceis. Na tentativa de interpretar esses registros, lembramo-nos de que foram feitos num momento de efervescência no ensino em Minas Gerais, nos primeiros anos de funcionamento de uma instituição criada mediante uma proposta ambiciosa do governo para reformar a escola pública, renovando a formação docente. Lembramo-nos, também, que todo esse movimento propunha uma escola progressista baseada no tripé biologia-psicologia-sociologia, trazendo para o campo da educação a contribuição de ciências como a medicina, a psicologia, a sociologia, entre outras, o que, em termos de ideário, fazia uma grande diferença na forma de conduzir o ensino.

Nesse sentido, o aspecto da repetição que aparece no trecho acima sobre os 81 fatos da multiplicação nos remete à crítica que pesava sobre a escola antiga, dita tradicional, pautada na ação de decorar, apelidada pejorativamente de decoreba, acusada de causar sofrimentos às crianças, oprimidas ou castigadas para decorar os fatos fundamentais. Percebe-se, então, nas anotações do caderno, a permanência de concepções pedagógicas tradicionais quanto à necessidade da memorização, mesmo que essas anotações revelem, amiúde, a presença de um discurso que insiste sobre a compreensão da criança como um de seus pontos cruciais.

Esse discurso se manifesta em vários outros exemplos que encontramos no caderno de Imene, como a anotação de que Kilpatrick ${ }^{10}$ fez experiências com três processos para verificar qual deles levava à maior rapidez e precisão, tendo-os aplicado a

\footnotetext{
${ }^{9} \mathrm{Na}$ última página do caderno que está em nossas mãos, Imene Guimarães registrou as palavras: "Continua no outro caderno."

${ }^{10}$ William Kilpatrick (1871-1954) foi discípulo de John Dewey no Teacher's College e trabalhou nessa instituição como professor de Filosofia da Educação no período de 1912 a 1937. É o idealizador do método de projetos, um procedimento didático direcionado para a aplicação da filosofia educacional de Dewey baseado na abordagem centrada na criança dos teóricos da educação progressiva. Ver http://education.stateuniversity.com/pages/2147/Kilpatrick-William-H-1871-1965.html. Acesso em: 17 jul.,
} 2012. 
crianças que não conheciam a multiplicação. Os processos são descritos como: 1) a memorização da tabuada; 2) o fornecimento, pelo professor, de uma chave com todos os fatos da multiplicação, seguido da realização de exercícios de multiplicação com a consulta a essa chave; 3) explicações dadas pelo professor a partir da adição, até chegar à interpretação da multiplicação pela adição. No registro que Imene produziu, o processo mais bem sucedido foi o último e a experiência viria confirmar que o trabalho feito por associação é mais eficiente. Esse argumento fundado nas experiências de Kilpatrick marca a insistência na compreensão da criança mais do que na memorização ou na simples consulta a informações a ela fornecidas.

No que se refere ao ensino da divisão, a preocupação com o entendimento da criança sobressai-se novamente. Assim, encontramos, à página 8 do caderno, o seguinte registro referente à explicação do algoritmo da divisão:

Todo o trabalho deve ser feito oralmente para depois passar a escryta. É preferível seguir um caminho longo sempre appelando pelo raciocínio, do que chegar ao resultado rapidamente pelo conhecimento de uma technica. A technica falha, o raciocínio guia. (Guimarães, 1932, p. 8)

Um aspecto muito acentuado, nos apontamentos do caderno, é o da apresentação gradativa das dificuldades no ensino da divisão. À página 17 Imene registra a recomendação da professora sobre o valor do trabalho de separação dos casos mais difíceis e mais fáceis da divisão, com o argumento de que isso é vantajoso para que as dificuldades sejam vagarosamente vencidas. Do contrário, está anotado, "o menino ficará com uma serie de pequenas difficuldades formando uma grande difficuldade, que muito prejudicará seu trabalho" (Guimarães, 1932, p. 17). Esse princípio, o da graduação das dificuldades, é recorrentemente mobilizado no ensino da divisão. Diversos registros referentes à organização da gradação das dificuldades da divisão estão espalhados nas páginas do caderno, como, por exemplo, na aula de 26 de agosto:

Vamos então organizar assim o trabalho -

$\left.1^{\circ}\right)$ divisores terminados em 0.

$2^{\circ}$ ) divisores terminados em 1,2

$3^{\circ}$ ) divisores terminados em 9,8

$4^{\circ}$ ) divisores terminados em $3,4,5,6,7$

$\left.5^{\circ}\right)$ quaesquer divisões. (Guimarães, 1932, p. 27).

Outro tema que nos parece digno de nota no caderno é o que nele é designado como Diagnóstico de erros. São focalizados, na aula de 27 de agosto de 1932, erros comuns de vários tipos nas divisões, sob o título Diagnóstico de erros. Por exemplo, na página 28, a divisão de 3173 por 5 aparece armada com 7 como o primeiro algarismo do quociente. Logo após, aparecem as palavras: "é um erro de facto fundamental; falta a conexão, precisamos dar a este menino exercícios com estes factos (Guimarães, 1932, p. 28)". Nota-se, assim, que a professora, ao comentar o erro, apresenta imediatamente às alunas uma recomendação para saná-lo: exercitar a criança nos fatos fundamentais essenciais cuja falta de domínio leva ao engano. 
Já ao final da aula de 27 de agosto, encontramos uma síntese acerca dos erros nas operações e do modo de as professoras lidarem com eles que muito se aproxima das melhores recomendações da psicologia educacional do período:

Os erros das operações não tem sempre a mesma causa e por isto o mesmo remedio não serve a todos. É portanto de grande vantagem fazer o diagnostico dos erros. Si pela frequencia deles nos exercícios pudermos perceber a causa, muito bem, senão pedirem ao menino que faça em voz alta para comprehendermos seu processo mental. Sabendo a causa do erro, o remédio será apropriado e produzirá effeitos rápidos. (Guimarães, 1932, p. 38).

As últimas aulas anotadas no caderno, de 31 de agosto e 2 de setembro, trazem prescrições de cunho teórico e metodológico sobre a abordagem da Aritmética na escola primária. Assim, ao abordar os objetivos da Aritmética, Alda Lodi, segundo a página 39 do caderno de Imene Guimarães, destacou o papel desse conhecimento no desenvolvimento físico da criança: "na composição dos alimentos, a proporção em que entra tal ou tal elemento, só a arithmetica é que pode determinar", bem como no desenvolvimento social do aluno dependendo "do modo como é tratada a matéria". Já quanto ao desenvolvimento intelectual da criança, a professora não considerou necessário deter-se em maiores explicações: "Desenvolvimento intellectual nem é preciso dizer" (Guimarães, 1932, p. 39).

É, porém, em relação à resolução de problemas de Aritmética que vamos encontrar um grande número de considerações. Referem-se elas, sobretudo, a diversas classificações possíveis para os problemas - reais, irreais, simples, complexos, concretos, abstratos, fáceis, difíceis -, sempre se tomando como referência o seu ensino para a criança da escola primária.

Leiamos alguns registros do caderno, nas páginas 39 a 42, na aula de 31 de agosto. No primeiro desses registros selecionado por nós e transcrito a seguir, nota-se que a aula de Alda Lodi acentua o relativismo quanto à simplicidade ou complexidade, concretude ou abstração de um problema - tudo depende de quem o resolve. Observe-se a recomendação às alunas-professoras em relação ao princípio de se percorrer, com a criança, o trajeto do concreto ao abstrato - cada situação precisa ser examinada de acordo com suas peculiaridades e circunstâncias:

Não podemos, vendo um problema, affirmar si é concreto ou abstracto porque isto depende da pessoa que o resolverá. Ex - Do Ford e do Chevrolet. É concreto em um logar onde seja comum viajar de automóvel e abstracto em outro onde não haja automovel. Como então vamos seguir o principio de ir do concreto ao abstracto? De accordo com a situação, pois somente ella pode dizer quando um problema é ou não concreto. (Guimarães, 1932, p. 39).

Na página 42, surgem explicações da professora acerca de uma classificação de problemas em simples e compostos de acordo com o número de operações necessárias à sua resolução: segundo alguns autores, um problema é simples se seu resultado depende da realização de uma só operação e complexo se requer várias operações. Alda Lodi, no entanto, parece discordar dessa classificação, já que as anotações de sua aluna dizem: 
Nem todo problema de uma operação é simples, nem todo de muitas operações é complexo. Muitas vezes reconhecer qual operação a ser feita é muito + difficil do que resolver um problema com várias operações. Problemas simples são os que estão mais dentro das experiencias das creanças quer tragam uma ou mais operações. Problemas complexos são os que estão fora das experiencias das creanças ou de quem vae resolvel-o. (Guimarães, 1932, p. 42).

Como se pode perceber, as ideias opostas de simples e complexo são remetidas, respectivamente, à sua maior ou menor proximidade em relação às experiências das crianças ou de quem quer que vá resolvê-los.

Do mesmo modo, a realidade ou irrealidade de um problema não se vincula, na prática docente da Aritmética com crianças, à oposição entre uma situação real ou uma fictícia. O real estaria, assim, como o simples e o complexo, diretamente conectado às experiências da criança. Seguem-se, nos registros, exemplos explicativos retirados dos contextos econômicos e socioculturais das cidades mineiras de Cachoeira do Campo e Muzambinho:

Não é necessário apenas que a situação exista, mas também que esteja dentro da esphera das experiências da creança. E sob este ponto de vista que vamos encarar a palavra real. Real - o que pode ser comprhendido pelo alumno. Segue-se que um problema pode ser real para uma classe e não sel-o para outra. Ex- Em Cachoeira do Campo há muitas pessôas que nunca viram um trem de ferro. Um problema sobre bondes seria irreal para a creança de lá. Trata-se de uma situação extranha. Há problemas que só se referem à localidade. Ex- Porque a Empreza de Vinhos Muzambinho diminuiu o salário de seus empregados, durante o anno passado? Este problema é real somente em Muzambinho. Aliás um optimo problema pois concorre para dar ao alumno uma penetração das cousas sociaes. (Guimarães, 1932, p. 50).

$\mathrm{Na}$ continuação da abordagem dos problemas reais, na aula da tarde de 2 de setembro, menciona-se que alguns professores chamam de real, na escola primária, a um problema que surge naturalmente, sem que seja exigida sua formulação pela professora. Por exemplo, na página 52, cita-se a situação de um menino encarregado da biblioteca:

Ex- Supponhamos um menino encarregado da biblioteca. Chegaram 169 livros; em cada prateleira da estante só cabem 25 livros. Todas as estantes estão cheias. Quantas estantes são necessárias para collocar os 169 livros? O problema surge, independente de formulação. (Ibid., p. 52).

A colocação da criança em primeiro plano é enfaticamente destacada ao longo dessas últimas aulas anotadas no caderno. A curiosidade e o interesse infantis são, por várias vezes, evocados explicitamente, em frases como as que reproduzimos a seguir:

A creança é curiosa; há problemas que fazem appelo a esta sua curiosidade. (lbid., p. 48).

Todo pensamento do menino é dominado pelo interesse. Toda apprendizagem deve estar dentro deste interesse. (Ibid., p. 47). 
À página 53 ressalta-se que, mesmo que o problema não seja propriamente da criança, caso se refira a uma atividade de seu interesse, ela o resolverá ${ }^{11}$. É preciso sublinhar, porém, um requisito essencial, nas concepções veiculadas pelo caderno de Metodologia da Aritmética, para que se possa resolver um problema: o domínio das operações e procedimentos da Aritmética. De fato, lê-se, na página 46: "Para o menino resolver um problema, elle precisa estar senhor dos processos arithmeticos; é necessario que elle possua um certo conhecimento numerico" (Ibid., p. 53). Na mesma linha de pensamento, encontramos as seguintes anotações:

Há professores que tendo em vista levar a creança a resolução de certos problemas começam dando estes problemas com números pequenos. Acontece que os meninos resolvem mas quando os numeros são maiores, o mesmo problema não é resolvido. Porque? Quando os meninos são pequenos o menino faz o calculo mentalmente e dá a resposta sem saber que operação effetuou. Os $\mathrm{n}^{\text {os }}$ sendo maiores, torna-se necessário a operação e os meninos não conseguem resolver o problema. (Guimarães, 1932, p. 54).

Nossa leitura do caderno nos mostra que as aulas de Metodologia da Aritmética na Escola de Aperfeiçoamento, além do aprendizado do como ensinar o conteúdo da disciplina, visam acentuar, junto às alunas-professoras, a centralidade da criança no processo educativo. As recomendações registradas apontam para o interesse da criança, a sua curiosidade e o seu prazer, mas também se direcionam para que essa criança aprecie a Aritmética como algo útil para a vida humana. Nesse sentido, atente-se para o seguinte trecho anotado no espaço correspondente à aula de 2 de setembro:

Vamos suppor uma professora que faz seu trabalho em torno de números e outra que o faz por meio de situações problemáticas. A $2^{\mathrm{a}}$ dará ao aluno 0 valor do $n^{\circ}$ no progresso da civilisação. A construção de uma ponte, de uma casa, de qualquer cousa que traga progresso para o logar, quando aproveitada pela professora, dará ao alumno uma attitude de apreciação para com o numero. (Ibid., p. 47).

Em consonância com a proposta de associação dos conhecimentos da Aritmética às coisas das sociedades humanas, Imene registra a preocupação manifestada na disciplina Metodologia da Aritmética mediante a expressão "Penetração das cousas sociais", que, conforme o texto do caderno, "será conseguida pela arithmetica, socialisada, com material tirado da própria sociedade." (Ibid., p. 47).

Como já foi comentado, a professora Alda Lodi não julgou necessário discorrer sobre o desenvolvimento intelectual propiciado pela Aritmética. No entanto, a ideia de que a Aritmética proporciona o progresso do pensamento infantil além dos conhecimentos aritméticos é posta em relevo na frase: "O menino precisa ganhar o habito de pensar; não queremos o pensamento só para a arithmetica." (Ibid., p. 46).

${ }^{11}$ O exemplo apresentado à mesma página do caderno é transcrito a seguir. "Ex- Os meninos vão visitar uma sapataria. Conversando com o sapateiro este the diz que tem bastante serviço. Põe, em media, por semana, 3 meias solas em sapatos a $5 \$ 000$ cada uma. Courinho no salto, as moças gastam muito. Põe 15 em media, a $1 \$ 500$ cada uma, etc. Os meninos, estando interessados, resolverão os problemas do sapateiro". 
Numa perspectiva em que o interesse da criança é o principal móvel de seu pensamento e em que a resolução de problemas é o principal objetivo da Aritmética, em conformidade com a vinculação desejada entre Aritmética e sociedade, "claro será que o material dos problemas deve ser pesado para que promova o desenvolvimento do pensamento." (Ibid., p. 48). Coerentemente, além dos exemplos de problemas que reproduzimos aqui, o caderno mostra referências a outros temas interessantes para figurar nos problemas da prática docente da Aritmética, como problemas relativos à casa da criança, sobre os quais se comenta o grande interesse que provocam, e os problemas de geografia e história: "comparação entre a produção de varias cidades, população, superfície, densidade. Factos históricos; há quanto tempo se deram?" (Ibid., p. 49), ressaltando-se uma vantagem adicional de tais problemas - "dar á creança o sentimento de civismo." (Ibid., p. 17).

O caderno tem 28 folhas, como já dissemos. Sua última página trata ainda da questão da abordagem a ser conferida, pelas alunas-professoras, em sua prática, à resolução de problemas aritméticos. Entretanto, a conclusão do caderno acontece com a anotação de Imene no espaço da terceira capa transcrita a seguir, que denota a percepção que a aluna tem do trabalho da professora de Metodologia da Aritmética da Escola de Aperfeiçoamento: "Si se conseguisse ensinar uma classe desde o $1^{\circ}$ anno, pelo processo aconselhado por $\mathrm{D}$. Alda, a arithmetica se tornaria para as creanças um verdadeiro instrumento para sua adaptação à vida e concorreria enormemente para tornalas mais felizes e melhores." (Guimarães, 1932, anotação na terceira capa).

\section{O caderno em sintonia com outros documentos}

Viñao (2008, p. 27), ao propor a consideração dos cadernos escolares como fonte histórica no contexto das práticas e pautas escolares, sociais e culturais de sua época, sublinha que ele é uma "fonte a utilizar em combinação com outras" e que seu uso precisa completar-se com outras fontes históricas diversificadas. O caderno de Imene Guimarães é, como dissemos, um dos muitos documentos integrantes do Arquivo Alda Lodi. Outros materiais desse acervo nos possibilitam compreender mais acerca da disciplina Metodologia da Aritmética sob a regência de Alda Lodi na Escola de Aperfeiçoamento.

Um desses materiais é um texto sem título ou data composto por 13 páginas datilografadas em tinta vermelha, com algumas anotações feitas à mão com caneta tinteiro preta, em papel sem pauta, amarelado pela ação do tempo. Mesmo não trazendo qualquer registro de data, o conteúdo desse texto nos permite afirmar que sua escrita foi feita em novembro ou dezembro de 1929, como esclareceremos logo à frente. São páginas soltas e numeradas, de dimensões $6,5 \mathrm{~cm}$ por $8,5 \mathrm{~cm}$, em bom estado de conservação e boas condições de legibilidade, apesar da existência de alguns pequenos borrões.

As primeiras linhas desse documento ${ }^{12}$ dizem: Em fins de agosto, quando de regresso de minha viagem aos E. Unidos, fui incumbida do trabalho - Methodologia da arithmetica na E. de A. Nesses trez meses alguma cousa foi feita, não muita pela escassez do tempo" (Lodi, 1929, p. 1).

\footnotetext{
${ }^{12}$ No presente texto, os trechos reproduzidos conservam a grafia usada por Alda Lodi em 1929.
} Hist. Educ. [online] Porto Alegre v. 18 n. 42 Jan./abr. 2014 p. $9-35$ 
Percebemos, desde logo, nessas palavras iniciais, que estamos diante de um relato em que Alda Lodi informa, possivelmente a colegas e superiores educacionais, o trabalho que havia realizado na disciplina Metodologia da Aritmética na Escola de Aperfeiçoamento (E. de A. na escrita) logo que voltou dos Estados Unidos. Como esse retorno da estadia no Teacher's College aconteceu em agosto de 1929, e o texto se refere a três meses depois, é possível datá-lo, com segurança, de novembro ou dezembro de 1929. Nesse material, estão presentes alguns aspectos que buscamos assinalar na análise anteriormente desenvolvida do caderno de Imene Guimarães, tais como a necessidade de vincular a Aritmética às situações reais da vida infantil e o propósito essencial de centralizar na criança a ação pedagógica:

Como Arith. não deve ser ensinada com o fim de arith. exclusivamente, á parte das necessidades da vida, sem attender ás sit. reaes que a creança encontra, mas sim ajudal-a a estimar, a medir, a comparar, a calcular, a tornal-a socialmente efficiente no manejo das sit. numéricas, entendemos iniciar nosso curso discutindo a creança e o programa escolar. Assim, sempre firmamos as bases do nosso trabalho - giral-o em torno da creança, aproveitando seus interesses imediatos como ponto de partida da educação. (Lodi, 1929, p. 1)

Numa segunda passagem que selecionamos no documento, Alda Lodi narra sua ação nos primeiros três meses como docente de Metodologia da Aritmética, mediante uma abordagem que contrapõe explicitamente a escola antiga, a que ensina matérias, à escola moderna, aquela que ensina a crianças:

Passámos depois a ver os característicos de escola nova, tratando-a como uma sociedade, vendo os alumnos individualmente, para conduzil-os ao seu maximo desenvolvimento, attendo ás differenças individuaes, ao meio, a todos os factores que influem no sentido quádruplo da educação - o desenvolvimento physico, intellectual, moral e social do individuo. Mas, hão de ponderar: si a cadeira é Methodologia da Arith., porq. entrar nesse campo que parece não se relacionar. Não seria melhor entrar na materia de uma vez? A razão está no seguinte: a escola antiga ensina materias, geographia, leitura, arith., historia. A escola moderna visa o desenvolvimento, ensina a creanças, ao invés de materias, tem por objectivo seu desenvolvimento, garantir-lhe as possibilidades de se conduzir por si própria, fazel-o senhor de s/ actos, fazel-o agente e julgador de suas acções. As desciplinas vêm pois, como meios desse crescimento e, como tal, arithmetica é uma dellas. (Lodi, 1929, p. 2)

Com a ortografia da época e o uso frequente de abreviaturas que marca a escrita de sua autora, os dois trechos acima reproduzidos são eloquentes quanto às propostas escolanovistas no sentido mais amplo, evidenciando o foco central na criança e seus interesses, a preocupação com seu desenvolvimento e a colocação dos conteúdos do ensino como meios para esse desenvolvimento. Alda Lodi comenta, em outras partes do documento, que as práticas escolares anteriores tornavam o trabalho árido, desinteressante, sem cunho de realidade, despertando nos alunos aversão pelos números. Evitar essa aversão implicaria, em suas palavras, basear a Aritmética nas atividades sociais, fazendo a criança "observar, comparar e nunca receber uma fórmula do professor" (Ibid., p. 4). A professora relata que, nos primeiros três meses após sua 
volta do Teacher's College, havia se empenhado em convencer as professoras quanto à necessidade de conhecer melhor a Aritmética "consumida" diariamente, nomeada por ela "aritmética social" ou "aritmética prática". Essa Aritmética comandaria "o que os meninos devem aprender, o que a sociedade delles exige", e simplificaria "o trabalho da mathematica, tornando-o mais pratico, mais atthraente, mais util, real” (Ibid., p. 8).

A harmonia entre o teor desse documento e o conteúdo das aulas da professora de Metodologia da Aritmética evidenciado nas anotações do caderno de sua aluna em 1932 é clara. A consonância pode ser percebida, ainda, entre o caderno e um segundo material do Arquivo Alda Lodi. Trata-se de um exemplar do Boletim n. 25, da União das Repúblicas Americanas $^{13}$, Série Sobre Educação, de junho de 1929, intitulado 0 ensino da arithmetica - novos methodos de arithmetica, de autoria de Margaretta Voorhees, inspetora da Escola Elementar Beaver de Boston, nos Estados Unidos. Uma nota que antecede o texto diz que ele e todos os demais da série sobre educação foram traduzidos do inglês, adaptados e preparados pela Seção de Cooperação Intelectual da União PanAmericana, responsável pelo financiamento das despesas de impressão. Uma segunda nota informa que o texto de Voorhees foi traduzido da revista Progressive Education, publicada em Washington, no segundo trimestre de 1928.

\footnotetext{
${ }^{13}$ Um texto na contracapa interna do livreto traz as seguintes informações: "A União Pan-Americana é uma instituição internacional mantida em Washington, D. C., pelas 21 Republicas americanas, a saber: Argentina, Bolivia, Brasil, Chile, Colombia, Costa Rica, Cuba, Equador, Estados Unidos, Guatemala, Haiti, Honduras, Mexico, Nicaragua, Panamá, Paraguay, Peru, Republica Dominicana, Salvador, Uruguay e Venezuela". Ainda segundo esse texto a União Pan-Americana foi constituída para voltar-se ao desenvolvimento e progresso do comércio, das relações de amizade e a promover melhor entendimento, mantendo a paz entre os países. Seu custeio era sustentado por cotas vindas da contribuição dos diversos países, baseadas nas suas respectivas populações e sua administração feita por um diretor geral e um subdiretor eleitos por um Conselho Diretor, formado pelo secretário de Estado dos Estados Unidos e representantes diplomáticos ou especiais, em Washington, dos demais governos americanos. Um corpo de especialistas internacionais, estatísticos, redatores, tradutores, compiladores, bibliotecários e taquígrafos era responsável pelas publicações dos boletins mensais em inglês, espanhol e português que registrariam o progresso pan-americano. Informa-se ainda que a União Pan-Americana achava-se instalada em um palácio construído mediante a generosidade de Andrew Carnegie e as contribuições das repúblicas americanas.
} 
Figura 3

Capa do Boletim n. 25 - O ensino da arithmetica: novos methodos de arithmetica, de Margaretta Voorhees, 1929.

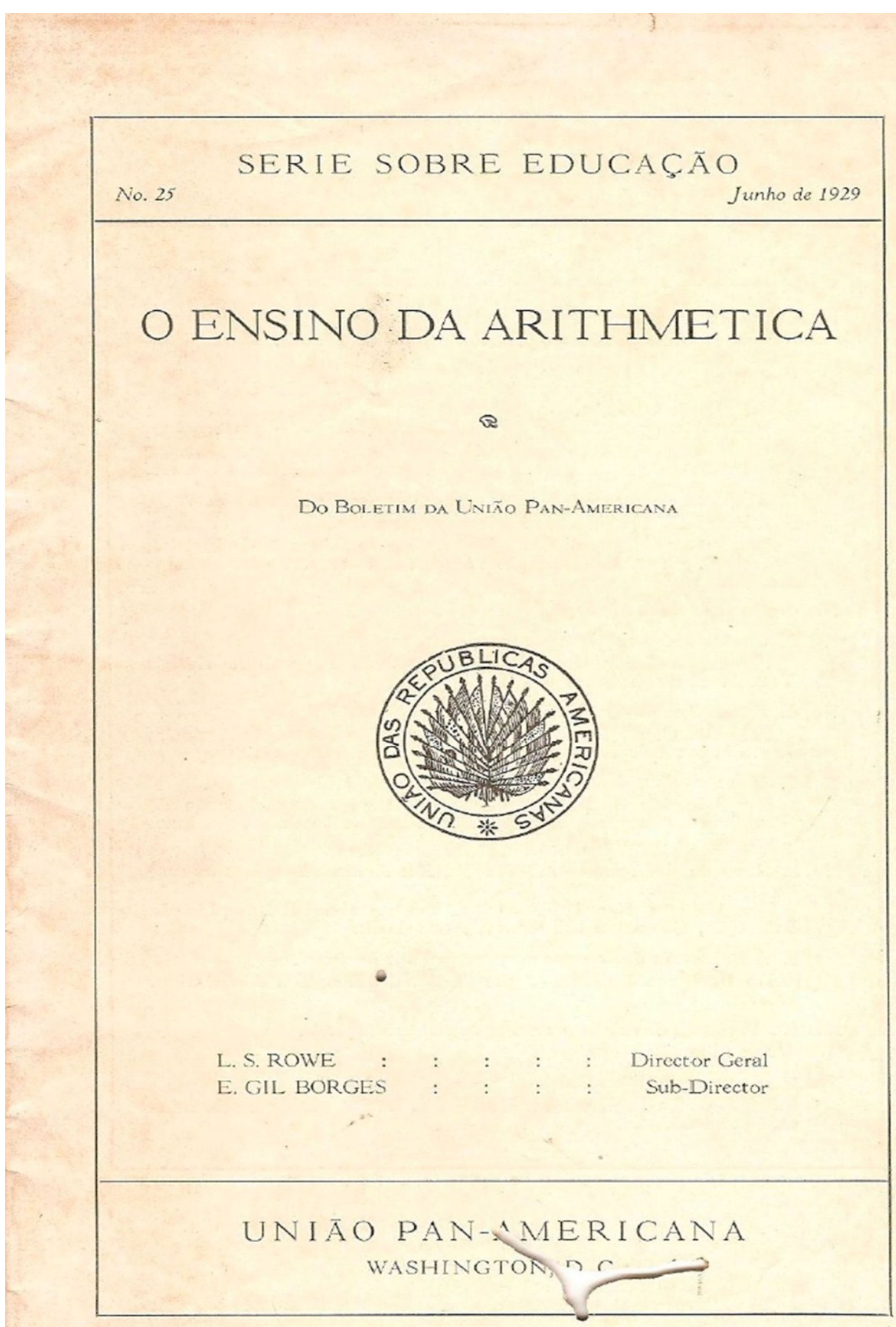


O artigo se inicia com uma crítica contundente ao ensino tradicional, fundado na memorização de todas as matérias escolares, dirigindo-se, em seguida, para o caso particular da Aritmética:

Emplastros educativos applicados á custa da colla da memória não mais se admittem nos novos typos de educação. Afirma a nova philosophia que cada matéria escolar deve se justificar, ou a titulo de nova opportunidade para descoberta e expressão ou como necessidade vital no desenvolvimento da creança, e que essa matéria precisa ser entretecida na sua vida mediante uso constante e esclarecido. A arithmetica não deve, por certo, constituir excepção a esta regra; no emtanto, mesmo nas escolas dedicadas a um esforço bem definido de transformar os velhos methodos rotineiros em experiências vitaes, esta matéria ainda apparece como emplastro, e de mais a mais, emplastro bem sem graça. (Voorhees, 1929, p. 1)

Na sequência, a autora contrapõe o ensino promovido até então da Aritmética, tida como disciplina mental e ensinada por meio de exercícios formais, e a orientação nova, na qual a criança deveria ser "o meio de desenvolvimento de qualquer matéria" (Ibid., p. 1). Voorhees salienta que, mesmo talvez sendo difícil "vitalizar a aritmética" (Ibid.), era necessário que essa matéria assumisse uma nova feição, para manter o lugar que lhe competia na vida da criança.

A sintonia entre o teor do artigo, o caderno de Imene Guimarães e o texto datilografado escrito por Alda Lodi no fim de 1929 pode ser percebida em muitos outros aspectos. Tendo em vista o papel proeminente da abordagem conferida aos problemas no caderno de Metodologia da Aritmética, especialmente no que diz respeito ao interesse da criança, destacamos esse aspecto num trecho do artigo de Margaretta Voorhees para evidenciar a semelhança de seu conteúdo com as anotações da aluna da Escola de Aperfeiçoamento:

Os problemas oriundos de assumptos escolares apresentam possibilidades quasi infinitas, podendo mesmo ser iniciados nos primeiros graus. Para que dêem resultado é necessário que estejam associados com algum interesse imediato. Por esse motivo torna-se difficil descrevel-os, todavia a seguinte lista incompleta dará alguma idéa de fontes possíveis. Encontram-se problemas em livros, em jornaes, problemas referentes aos negócios dos paes, problemas que a mãe de família encontra no lar, problemas nos brinquedos [...], em estudos cívicos, na industria, na historia, no estudo dos povos, no desenvolvimento da geographia, e assim por deante. (Voorhees, 1929, p. 8)

Um terceiro documento do Arquivo Alda Lodi nos traz mais possibilidades de compreender a atuação da professora na disciplina Metodologia da Aritmética na Escola de Aperfeiçoamento retratada pelo caderno. Trata-se de um texto datilografado em inglês que apresenta, no centro de sua folha de rosto, as inscrições: 
Education 268 B

Prof. C. B. Upton

May, 13, 1929

Alda Lodi.

A pesquisa de Fonseca (2010) indica C. B. Upton como o professor da disciplina Metodologia da Aritmética cursada por Alda Lodi no Teacher's College, e a expressão Education 268 B representa, provavelmente, o código dessa disciplina. Clifford B. Upton (1877-1957) foi professor da instituição de 1907 até sua aposentadoria em $1942^{14}$. O documento se afigura como um conjunto não publicado de notas para a disciplina Metodologia da Aritmética, não tem título e é composto por uma página de apresentação e 36 páginas numeradas. Após as primeiras seis páginas, que contêm orientações gerais sobre o ensino da Aritmética, encontram-se listas de tópicos de Aritmética específicos a serem abordados no jardim da infância (idade de 4 a 6 anos) e em cada um dos quatro primeiros anos da escola elementar norte-americana.

$\mathrm{Na}$ apresentação, Upton afirma que as abordagens usuais da Aritmética escolar não satisfaziam seus objetivos de maneira lógica e eficiente para a maioria das crianças. Transcrevendo palavras de John Dewey em The child and the curriculum, o autor ressalta a necessidade de um enfoque mais abrangente e adaptável da matéria que tivesse a criança como o ponto de partida, centro e ponto de chegada, e declara sua intenção no texto - apresentar um esqueleto simples daquilo que gostaria de ver acontecer na escola primária de quatro anos: tentar conectar o interesse, a capacidade e a experiência da criança dessa idade ao trabalho que se deseja fazer.

$\mathrm{Na}$ página que sucede essa apresentação, o primeiro parágrafo concerne à dimensão social que se pretendia que a Aritmética assumisse na educação primária, visível, como procuramos mostrar, nas anotações de Imene Guimarães. O autor afirma que a matéria não deveria ser ensinada por si própria, desconsiderando-se as necessidades da vida, mas sim "ajudar a criança a estimar, medir, comparar e calcular, para torná-la eficiente em lidar com as situações numéricas que ela provavelmente encontrará" (Upton, 1929, p. 1). Upton prossegue, na mesma página, aludindo à aprendizagem realizada por meio das experiências infantis, que também deveria ocorrer em relação aos números:

A criança entra na escola com alguma ideia de número. Essa ideia deveria crescer, durante seu percurso escolar, exatamente como aconteceu antes de ela entrar na escola - através de experiências. Nossa vida se mede pelo grau com que respondemos ao ambiente, que é uma fonte real de materiais educacionais. Como a educação multiplica os pontos de contato, tornando o ambiente mais significativo, em consequência, ela aprimorará nosso estilo de vida, porque veremos mais possibilidades de geri-lo e controlá-lo. [...] Se enchermos o ambiente da criança com oportunidades para números, se mudarmos as condições da escola de modo a fazer as relações numéricas mais significativas, o desenvolvimento quanto aos números estará assegurado. (Ibid., p. 1)

Essas páginas iniciais referem-se, ainda, como o caderno de Imene, ao interesse e ao prazer da criança, e recomendam a aplicação da Aritmética a problemas da vida real.

\footnotetext{
${ }^{14}$ Conforme http://journals.tc-library.org/index.php/matheducation/issue/view/37. Acesso em 3 ago., 2012. 
Upton afirma que a Aritmética é "um instrumento social para iluminar e clarificar conceitos sociais" (p. 8). Na linha que vimos Alda Lodi aconselhar a suas alunas-professoras da Escola de Aperfeiçoamento nos registros de Imene, Upton (1929, p. 7) enumera como objetivos gerais a serem atingidos pelo ensino da Aritmética o conhecimento e controle automático dos imutáveis princípios e operações fundamentais; a habilidade de perceber relações e capacidade de interpretar as expressões numéricas dessas relações; a aquisição da capacidade de usar as habilidades e conceitos fundamentais na resolução de problemas.

Poderíamos, dada a riqueza do Arquivo Alda Lodi, tratar ainda de outros de seus materiais sintonizados com o caderno de Imene Guimarães. Preferimos, porém, concluir esta seção colocando em evidência algumas convergências do caderno com o conteúdo de livros dirigidos a educadores e professores, textos estes exteriores ao acervo de que nos valemos.

Por exemplo, a oposição entre o ensino antigo e o ensino novo da Aritmética, com ênfase no papel do professor e do aluno e na proposta fundada nas experiências da criança, nem sempre explícita no caderno, mas patente nos outros materiais que aqui mobilizamos, é ressaltada, ainda nas décadas posteriores, em publicações de orientação para educadores que apresentam um capítulo específico sobre o ensino da Aritmética no contexto da escola nova, progressiva ou ativa. Em Moreira (1960), encontramos a seguinte passagem:

Dir-se-á que [...] nós levaremos muito mais tempo do que pelo processo antigo, em que o professor propunha a questão e a resposta, cabendo à criança reter ambas as coisas, à custa de repetição ou exercícios de memória. Realmente assim é. A diferença, porém, é que, no primeiro caso, isto é, no ensino mediante prática de conteúdo social, a criança adquire as noções que deve aprender de modo permanente, porque elas terão resultado de experiências vividas, que permanecem no espírito (...) Já no segundo caso, dos exercícios formais, em que a memória verbal, auditiva ou escrita, desempenha o principal papel, a criança pode adquirir habilidades "papagaiando" tabuadas, soluções de problemas fictícios, regras, símbolos etc., sem entretanto, saber porque isso é assim, nem como utilizar tais coisas. [...] Não vemos, portanto, outra forma de aprender número, medida, cálculo, senão a indicada, isto é, através da experiência concreta, realmente vivida e por isso, socialmente útil. (Moreira, 1960, p. 260)

Especificamente sobre a resolução de problemas aritméticos, Aguayo (1970), editado no Brasil em 1970, mas publicado originalmente em 1932, contrasta os problemas da antiga didática, irreais e inúteis, com os da nova didática, reais e úteis:

Era postulado da antiga didática a doutrina da educação pelo esforço. Daí o sistema de exercitar os alunos em problemas tão abstratos e difíceis que suprimiam todo gosto e interesse pela aritmética. Ademais, os problemas eram quase sempre irreais, absurdos ou ridículos, desprovidos de toda utilidade e sem nenhuma relação com as necessidades econômicas do meio social. A nova didática combate energicamente esses erros e aplica na escolha dos problemas os princípios de utilidade, motivação e relação estreita com a vida real. Os problemas que as crianças devem resolver são 
os que estimulam o pensamento reflexivo, interessam o aluno e procuram obter resultados valiosos em muitas situações da vida de todo dia. (Aguayo, 1970, p. 269)

A sintonia entre o conteúdo dos materiais selecionados no Arquivo Alda Lodi aqui contemplados e as orientações veiculadas por obras como as dos autores citados acima é clara. Outros textos, particularmente os manuais para professores da escola primária publicados no longo período em que teve repercussão, no Brasil, o ideário das diversas versões daquilo que se chamou de Movimento da Escola Nova, também apresentam, no que se refere às propostas de ensino da Aritmética, aspectos comuns com as anotações do caderno de Imene Guimarães.

No entanto, o caderno contemplado no presente estudo se diferencia desses outros textos por possibilitar, no campo específico da educação matemática, o contato com uma reforma educativa específica, em um de seus aspectos mais importantes - o da formação de professoras que já estavam em atividade na escola mineira naquele momento e que tiveram a oportunidade de frequentar a Escola de Aperfeiçoamento ${ }^{15}$.

\section{Para concluir, algumas considerações}

O caderno estudado por nós permite observar os conteúdos presentes em uma parte da disciplina Metodologia da Aritmética ministrada na Escola de Aperfeiçoamento de Minas Gerais em 1932. Parece-nos inquestionável o valor desse documento para a compreensão do objeto específico constituído pelas propostas de ensino da Aritmética nesse tempo e lugar, sob o signo das reformas de cunho escolanovista realizadas pelo governo estadual.

Entretanto, é importante considerar o caderno sob outro ponto de vista - tomá-lo como um documento que é produto de uma instituição específica, a escola. Precisamos, assim, vê-lo como um dispositivo escolar, ou seja, atentar para o seu caráter de conjunto de práticas discursivas produzidas pela escola. Em nosso caso, o caderno de Imene Guimarães, da disciplina Metodologia da Aritmética ministrada pela professora Alda Lodi, representa um suporte em que se inscrevem práticas discursivas escolares, articuladas de determinado modo, gerando um efeito (Gvirtz, 1997; Gvirtz; Larrondo, 2008).

$\mathrm{Na}$ leitura do caderno, em associação com outros materiais do Arquivo Alda Lodi, pode-se perceber o "sentido da natureza ativa e transformadora do sujeito" (Rockwell, 2005, p. 29), quando observamos Alda Lodi tomando posse dos recursos culturais compostos por sua experiência, na qual tem relevo particular a passagem pelo Teacher's College, e utilizando-os na sala de aula da Escola de Aperfeiçoamento em Belo Horizonte, na formação das professoras que, nas salas de aula da educação pública estadual de Minas Gerais, lecionariam às crianças da escola primária os conhecimentos ligados aos números e às operações.

Imene Guimarães, por sua vez, participa dessas práticas discursivas de modo particular. É perceptível, em alguns registros do caderno, que a aluna-professora não se

\footnotetext{
${ }^{15}$ Segundo Prates (1989), as docentes eram indicadas para a Escola de Aperfeiçoamento por pessoas de notória importância na rede estadual de ensino, como o próprio secretário ou o inspetor geral da Instrução. Além disso, tinham influência na indicação das professoras que viriam para a capital realizar o curso da Escola de Aperfeiçoamento integrantes de destaque nas sociedades do interior mineiro, como padres, políticos e juízes.
} 
limitou a transcrever trechos possivelmente escritos na lousa ou mesmo ditados por dona Alda. Ela, tal como sua professora, desenvolvendo uma ativa prática de apropriação, insere, em suas anotações, excertos que associaríamos, mais facilmente, à oralidade, como "vamos fazer a creança comprehender devagarinho [...] se tivermos pressa, o menino não comprehende", à página 3, e outros já citados neste estudo. Há, ainda, evidentemente, as marcas próprias da escrita de Imene: uso de abreviaturas, sublinhados, disposição do texto nas páginas, que singularizam esse caderno de Metodologia da Aritmética na Escola de Aperfeiçoamento em 1932. O caderno de Imene se distinguiria, ainda, entre outros cadernos de professoras-alunas da mesma classe, pelo detalhamento dos registros nele encontrados. O fato de esse caderno ter permanecido por tanto tempo entre os papéis guardados de Alda Lodi se afigura como um indicativo da consideração de sua relevância pela professora de Metodologia da Aritmética.

Todavia, o caderno, mais do que de suas enunciadoras, Alda Lodi e Imene Guimarães, nos informa acerca de seus próprios enunciados, isto é, como propõem Gvirtz e Larrondo (2008, p. 44) ao refletir sobre o uso dos cadernos escolares como fontes, "as práticas discursivas que levam adiante o caderno não refletem o dito, feito ou pensado por seus autores individuais, entendidos como sujeitos unitários." Assim, o que é possível ver no caderno de Imene Guimarães, quando a professora é Alda Lodi, são enunciados distintivos que não podem ser diretamente atribuídos a suas autoras, a professora e a aluna.

Essas considerações conduzem a pensarmos no caderno de Imene Guimarães não como um sintoma de uma época que vinculamos às políticas educacionais mineiras e ao ideário escolanovista. Nele, podemos ver uma instância de discurso escolar próprio no qual repercutem, certamente, discursos científicos sobre a aprendizagem da Aritmética pela criança no seio das doutrinas escolanovistas e discursos políticos em Minas Gerais no momento das reformas de 1927. Ambos os discursos se articulam na trama do caderno, talvez desmanchando sua própria trama, na linguagem de Gvirtz e Larrondo (2008, p. 42), para gerar outro discurso, o escolar.

\section{Referências}

AGUAYO, Alfredo Miguel. Didática da escola nova. São Paulo: Companhia Editora Nacional, 1970.

CHARTIER, Anne-Marie. Os cadernos escolares: organizar os saberes, escrevendo-os. Revista de Educação Pública. Cuiabá, v.16, n. 32, 2007, p. 13-33.

CHARTIER, Anne-Marie. Práticas de leitura e escrita: história e atualidade. Belo Horizonte: Ceale/Autêntica, 2007a.

CHARTIER, Anne-Marie. Um dispositivo sem autor: cadernos e fichários na escola primária. Revista Brasileira de História da Educação. Campinas, n. 3, 2002, p. 9-26.

FONSECA, Nelma Marçal Lacerda. Alda Lodi, entre Belo Horizonte e Nova lorque: um estudo sobre formação e atuação docentes - 1912-1932. Belo Horizonte: UFMG, 2010. 159f. Dissertação (mestrado em Educação). Faculdade de Educação, Universidade Federal de Minas Gerais.

GUIMARÃES, Imene. Caderno. Belo Horizonte, 1932. 
GVIRTZ, Silvina. Del curriculum prescrito al curriculum enseñado: uma mirada a los cuadernos de clase. Buenos Aires: Aique, 1997.

GVIRTZ, Silvina. El discurso escolar a través de los cuadernos de clase. Argentina (1930 1970). Buenos Aires: Eudeba, 1999.

GVIRTZ, Silvina; LARRONDO, Marina. Os cadernos de classe como fonte primária de pesquisa: alcances e limites teóricos e metodológicos para sua abordagem. In: MIGNOT, Ana Cristina Venancio (org.). Cadernos à vista: escola, memória e cultura escrita. Rio de Janeiro: Uerj, 2008, p. 35-48.

HÉBRARD, Jean. Lo spazio grafico del quaderno scolastico in Francia tra Otto e Novecento. In: ANTONELLI, Quinto; BECCHI, Egle (ed.). Scritture bambine: testi infantili tra passato e presente. Roma-Bari: Laterza, 1995, p. 145-175.

LEME DA SILVA, Maria Célia; VALENTE, Wagner Rodrigues. A matemática moderna em Portugal: o que dizem os cadernos escolares dos alunos? Quadrante. Lisboa, v. 17, n. 1, 2008, p. 77-92.

LODI, Alda. [Relato de atividades desenvolvidas nos três primeiros meses como docente da Escola de Aperfeiçoamento]. Belo Horizonte, não publicado, 1929.

MIGNOT, Ana Cristina Venancio (org.). Cadernos à vista: escola, memória e cultura escrita. Rio de Janeiro: Uerj, 2008.

MIGNOT, Ana Cristina Venancio. Um objeto quase invisível. In: MIGNOT, Ana Cristina Venancio (org.) Cadernos à vista: escola, memória e cultura escrita. Rio de Janeiro: Uerj, 2008a, p. 7-13.

MOREIRA, João Roberto. Teoria e prática da escola elementar: introdução ao estudo social do ensino primário. Rio de Janeiro: Inep/CBPE, 1960.

PEIXOTO, Ana Maria Casasanta. Uma nova era na escola mineira: a reforma Francisco Campos e Mário Casassanta (1927-1928). In: LEAL, Maria Cristina; PIMENTEL, Marília Araújo Lima. História e memória da escola nova. São Paulo: Loyola, 2003, p. 75-115.

PERES, Eliane. Um estudo da história da alfabetização através de cadernos escolares (1943-2010). Cadernos de História da Educação. Uberlândia, v. 11, n. 1, 2012, p. 93-106.

PRATES, Maria Helena. A introdução oficial do movimento de escola nova no ensino público de Minas Gerais: a Escola de Aperfeiçoamento. Belo Horizonte: UFMG, 1989. 232f. Dissertação (mestrado em Educação). Faculdade de Educação, Universidade Federal de Minas Gerais.

PRATES, Maria Helena. Escola de aperfeiçoamento: teoria e prática na formação de professores. In: PRATES, Maria Helena. Lições de Minas: 70 anos da Secretaria de Educação. Belo Horizonte: Governo do Estado de Minas Gerais/Secretaria da Educação, 2000, p. 66-83.

ROCKWELL, Elsie. La apropriación: um proceso entre muchos que ocurren em âmbitos escolares. In: SOMEHIDE. Anuario de la Sociedad Mexicana de Historia de la Educación. Barcelona: Pomares, 2005, p. 28-38.

SOUZA, Rosa Fátima. História da organização do trabalho escolar e do currículo no século XX: ensino primário e secundário no Brasil. São Paulo: Cortez, 2008.

UPTON, Clifford Brewster. [Education 268 B]. Nova lorque, não publicado, maio de1929.

VIDAL, Diana Gonçalves. Cultura e prática escolares: uma reflexão sobre documentos e arquivos escolares. In: SOUZA, Rosa Fátima. VALDEMARIN, Vera Teresa (org.). $A$ 
cultura escolar em debate: questões conceituais, metodológicas e desafios para a pesquisa. Campinas: Autores Associados, 2005, p. 3-30.

VIDAL, Diana Gonçalves; FARIA FILHO, Luciano Mendes de. Reescrevendo a história do ensino primário: o centenário da lei de 1827 e as reformas de Francisco Campos de Fernando de Azevedo. In: VIDAL, Diana Gonçalves; FARIA FILHO, Luciano Mendes de. As lentes da história. Campinas: Autores Associados, 2005, p. 7-39.

VIÑAO, Antonio. Os cadernos escolares como fonte histórica: aspectos metodológicos e historiográficos. In: MIGNOT, Ana Cristina Venancio (org.). Cadernos à vista: escola, memória e cultura escrita. Rio de Janeiro: Uerj, 2008, p. 15-28.

VIÑAO, Antonio. Sistemas educativos, culturas escolares y reformas: continuidades y cambios. Madrid: Morata, 2002.

VIÑAO, Antonio. Tiempos escolares, tiempos sociales: la distribuición del tempo y del trabajo em la enseñanza primaria em Espanha (1838-1936). Barcelona: Ariel Practicum, 1998.

VOORHEES, Margaretta. O ensino da arithmetica: novos métodos de arithmetica. Boletim da União Pan-Americana - serie sobre educação. Washington, DC, n. 25, jun. 1929.

NELMA MARÇAL LACERDA FONSECA é mestre em Educação pela Universidade Federal de Minas Gerais e integra o Centro de Estudos e Pesquisas sobre História da Educação - Gephe/FaE/UFMG.

Endereço: Rua Professor Lincoln Continentino, 436/302 - 31170-230 - Belo Horizonte - MG - Brasil.

E-mail: nelmarcal@yahoo.com.br.

DIOGO ALVES DE FARIA REIS é doutorando em Educação pela Universidade Federal de Minas Gerais e professor no Centro Pedagógico da Universidade Federal de Minas Gerais.

Endereço: Avenida Antônio Carlos, 6627 - 31270-901 - Belo Horizonte - MG Brasil.

E-mail: diogofaria.ufmg@gmail.com.

MARIA LAURA MAGALHÃES GOMES é doutora em Educação pela Universidade Estadual de Campinas, professora no Departamento de Matemática e no Programa de Pós-Graduação em Educação da Universidade Federal de Minas Gerais.

Endereço: Avenida Antônio Carlos, 6627 - 31270-901 - Belo Horizonte - MG Brasil.

E-mail: mlauramgomes@gmail.com. 
LUCIANO MENDES DE FARIA FILHO é doutor em Educação pela Universidade de São Paulo e professor titular na Faculdade de Educação da Universidade Federal de Minas Gerais.

Endereço: Avenida Antônio Carlos, 6627 - 31270-901 - Belo Horizonte - MG Brasil.

E-mail: lucianomff@uol.com.br.

Recebido em 12 de agosto de 2013.

Aceito em 15 de novembro de 2013. 